\title{
PENGARUH PENGGUNAAN TEKNOLOGI INFORMASI DAN KEAHLIAN PEMAKAI TERHADAP KUALITAS INFORMASI AKUNTANSI (STUDI EMPIRIS PADA PEMERINTAH KABUPATEN MINAHASA SELATAN)
}

\author{
Cornelia Ferny Jansen ${ }^{1}$, Jenny Morasa ${ }^{2}$, Anneke Wangkar ${ }^{3}$ \\ 1,2,3 Akuntansi, Fakultas Ekonomi dan Bisnis, Universitas Sam Ratulangi, Jl. Kampus Bahu, Manado, 95115, \\ Indonesia \\ E-mail : Corneliafjansen@gmail.com
}

\begin{abstract}
Information is the result of data processing that gives meaning and benefit. Thus, information systems have an important role in relation to the quality of accounting information. The growing information system used then the resulting information will be better and will provide various facilities on the activities of government agencies in order to improve the quality of accounting information. This study aims to determine how the influence of the use of information technology and user expertise on the quality of accounting information. The sample in this research consist of 30 SKPD in South Minahasa Regency. Data analysis technique used is multiple linear regression analysis. The results showed that the use of information technology has a significant positive effect on the quality of accounting information as well as the expertise of users who have a significant positive effect on the quality of accounting information.
\end{abstract}

Keywords : Information, Information Technology, User Expertise, Quality Accounting Information

\section{PENDAHULUAN}

Instansi pemerintah daerah bertanggung jawab untuk memenuhi akuntabilitas dan harapan masyarakat. Dalam rangka mewujudkan pelayanan yang maksimal, organisasi dan instansi dalam sektor publik harus memiliki tata kelola manajemen yang baik (good governance), sehingga dalam kinerjanya dapat menghasilkan manfaat yang sebesar-besarnya bagi masyarakat. Selain itu, untuk mewujudkan kinerja yang baik maka pemerintah daerah harus dapat mengambil keputusan yang tepat yang akan dituangkan dalam bentuk program kerja dengan tujuan mensejahterakan masyarakat. Salah satu media pertimbangan dalam pengambilan keputusan yang tepat adalah informasi akuntansi. Informasi akuntansi yang baik mencerminkan keadaan yang sebenarnya yang diinterpretasikan dalam bentuk laporan keuangan dengan mengikuti standar akuntansi yang berlaku.

Menurut Azhar Susanto (2013:38), Informasi adalah hasil pengolahan data yang memberikan arti dan manfaat. Maka, sistem informasi memiliki peran yang penting dalam kaitannya dengan kualitas informasi akuntansi. Semakin berkembangnya sistem informasi yang digunakan maka informasi yang dihasilkan akan semakin baik dan akan memberikan berbagai kemudahan pada kegiatan instansi pemerintah dalam rangka meningkatkan kualitas informasi akuntansinya. Sistem informasi yang telah banyak digunakan oleh instansi pemerintah adalah Sistem Informasi Akuntansi berbasis Komputer (Computer based information system).

Sistem informasi berbasis komputer merupakan kumpulan dari berbagai perangkat keras (hardware) dan perangkat lunak (software) yaitu dengan mengolah data menjadi informasi yang dapat memberikan manfaat bagi penggunanya. Komponen sistem informasi disebut dengan teknologi informasi. Dengan adanya teknologi informasi akan lebih meningkatkan pelayanan yang diberikan instansi pemerintah. Teknologi informasi yang 
digunakan haruslah teknologi yang up to date agar informasi yang dihasilkan lebih tepat guna. Karena teknologi informasi akan terus mengalami perkembangan dari waktu ke waktu seiring dengan perkembangan zaman maka dibutuhkan orang-orang yang ahli dibidang sistem informasi yang memahami dan dapat mengoperasikan dengan baik suatu sistem sehingga dapat menghasilkan informasi akuntansi yang dapat digunakan dalam pengambilan keputusan dalam rangka peningkatan kinerja pemerintah. Keahlian pemakai sangat berperan penting dalam hal ini, karena seringkali ditemukan di lapangan teknologi informasi tidak dapat menghasilkan informasi yang akurat sehingga kurang memberikan manfaat bagi instansi. Hal ini terjadi karena pemakai tidak memiliki keahlian yang memadai untuk mengoperasikan suatu sistem berbasis teknologi komputer dengan maksimal.

Dalam konteks pengelolaan keuangan, Pemerintah Daerah Kabupaten Minahasa Selatan juga menggunakan Sistem Informasi yaitu Sistem Informasi Manajemen Daerah (SIMDA). Sistem Informasi Manajemen Daerah (SIMDA) yang digunakan oleh Pemerintah Kabupaten Minahasa Selatan ditujukan dalam proses penganggaran sampai dengan pelaporan keuangan. Dalam pelaporan setiap SKPD wajib menyajikan informasi akuntansi dalam bentuk laporan keuangan. Sesuai dengan PP nomor 08 Tahun 2006 tentang Pelaporan Keuangan dan Kinerja Instansi Pemerintah yang menyatakan bahwa pasal 5 ayat (2): Laporan Keuangan Kementerian Negara/Lembaga/Satuan Kerja Perangkat Daerah setidak-tidaknya terdiri dari: a. Laporan Realisasi Anggaran; b. Neraca; dan c. Catatan atas Laporan Keuangan.

Dalam hal ini Pemerintah Kabupaten Minahasa Selatan oleh setiap SKPD harus memiliki teknologi informasi yang berkualitas agar mendapatkan kualitas informasi akuntansi dalam menjalankan Sistem Informasi Manajemen Daerah (SIMDA) serta penyajiannya dalam bentuk laporan keuangan yang berkualitas dan bisa dipertanggungjawabkan.

Berdasarkan uraian tersebut, penulis tertarik untuk mengambil sebuah judul "Pengaruh Penggunaan Teknologi Informasi dan Keahlian Pemakai terhadap Kualitas Informasi Akuntansi”.

Berdasarkan latar belakang tersebut, maka rumusan masalah dalam peneitian ini adalah sebagai berikut:

1. Apakah penggunaan teknologi informasi berpengaruh terhadap kualitas informasi akuntansi pada Satuan Kerja Perangkat Daerah (SKPD) di Kabupaten Minahasa Selatan?

2. Apakah keahlian pemakai berpengaruh terhadap kualitas informasi akuntansi Satuan Kerja Perangkat Daerah (SKPD) di Kabupaten Minahasa Selatan?

\section{TINJAUAN PUSTAKA}

\subsection{Kualitas Informasi Akuntansi}

Ong et al. (2009:399) berpendapat bahwa kualitas informasi dapat diartikan pengukuran kualitas konten dari sistem informasi. Negash et al. (2003:758) menjelaskan kualitas informasi adalah suatu fungsi yang menyangkut nilai dari keluaran informasi yang dihasilkan oleh sistem. Berdasarkan beberapa pendapat para ahli, dapat disimpulkan bahwa kualitas informasi adalah suatu pengukuran yang berfokus pada keluaran yang diproduksi oleh sistem, serta nilai dari keluaran bagi pengguna.

Informasi akuntansi merupakan output yang dihasilkan oleh suatu sistem informasi akuntansi. Informasi akuntansi inilah yang nantinya akan digunakan dalam pengambilan keputusan. Keputusan yang dimaksud merupakan keputusan ekonomi yang digunakan dalam menentukan pilihan dalam memutuskan tindakan apa yang akan diambil nantinya. Salah satu informasi akuntansi yang dihasilkan oleh suatu sistem adalah laporan keuangan, dalam hal ini adalah laporan keuangan yang disajikan oleh instansi pemerintah. Dalam penelitian ini, 
instansi pemerintah yang dimaksud adalah Satuan Kerja Perangkat Daerah (SKPD) di Kabupaten Minahasa Selatan. Menurut penjelasan PP nomor 08 Tahun 2006 tentang Pelaporan Keuangan dan Kinerja Instansi Pemerintah bahwa Satuan Kerja Perangkat Daerah adalah organisasi/lembaga pada pemerintah daerah yang bertanggung jawab kepada gubernur/bupati/walikota. Laporan tersebut disajikan sebagai pertanggungjawaban pelaksanaan APBD pada Satuan Kerja Perangkat Daerah yang bersangkutan dan menyampaikannya kepada gubernur/bupati/walikota melalui Pejabat Pengelola Keuangan Daerah. Mengingat pentingnya manfaat informasi akuntansi yang disajikan dalam laporan keuangan SKPD, maka informasi akuntansi yang dihasilkan suatu sistem informasi haruslah informasi yang berkualitas.

Hal tersebut sesuai dengan PP nomor 71 tahun 2010 tentang Standar Akuntansi Pemerintah (SAP) yang menyatakan bahwa karekteristik kualitatif laporan keuangan adalah ukuran-ukuran normatif yang perlu diwujudkan dalam informasi akuntansi sehingga dapat memenuhi tujuannya. Keempat karekteristik berikut ini merupakan prasyarat normatif yang diperlukan agar laporan keuangan dapat memenuhi kualitas yang dikehendaki, yaitu:

1. Relevan

2. Andal

3. Dapat dibandingkan

4. Dapat dipahami

\subsection{Penggunaan Teknologi Informasi}

Dua teknologi yang mendasari teknologi informasi adalah teknologi komputer dan teknologi komunikasi. Jadi teknologi informasi adalah gabungan antara teknologi komputer dan teknologi komunikasi. Teknologi informasi meliputi perangkat keras, perangkat lunak dan komponen sistem terkait yang digunakan organisasi untuk menciptakan sistem informasi terkomputerisasi (Simkin, Norman \& Rose, 2013). Penggunaan teknologi informasi didefenisikan sebagai penggunaan teknologi komputer yang berhubungan dengan pengolahan data menjadi sebuah informasi, dan proses penyaluran data/informasi tersebut dalam batas ruang-ruang waktu tertentu (Hamdani Harfan, 2012). Penggunaan teknologi informasi dapat diartikan sebagai seberapa optimalkah penggunaan teknologi komputer dalam penyusunan laporan keuangan. Ukuran penggunaan teknologi informasi dapat dilihat menurut Hamdani Harfan (2012) sebagai berikut:

1. Memiliki komputer yang cukup

2. Jaringan internet

3. Pemanfaatan jaringan komputer (lan)

4. Proses akuntansi secara komputerisasi

5. Pengolahan data menggunakan software

6. Sistem informasi yang terintegrasi

7. Jadwal pemeliharaan peralatan secara teratur.

Teknologi informasi selain sebagai teknologi komputer untuk memproses dan penyimpanan informasi juga berfungsi sebagai teknologi komunikasi untuk penyebaran informasi. Komputer juga sebagai salah satu komponen dari teknologi informasi yang merupakan alat yang bisa melipatgandakan kemampuan yang dimiliki dan komputer juga bisa mengerjakan sesuatu yang mungkin manusia tidak mampu melakukannya. Dengan komputer, informasi yang dihasilkan dapat tepat pada waktunya dan tepat nilainya. Perkembangan teknologi juga mempengaruhi Sistem Informasi Keuangan Daerah dalam menyajikan informasi akuntansi berupa laporan keuangan. SKPD sebagai instansi pemerintah yang wajib menyajikan laporan keuangan menggunakan teknologi komputer dan software untuk memproses data menjadi laporan keuangan. Salah satu aplikasi sederhana yang digunakan adalah Microsoft Excel dengan kesatuan rumus-rumus yang secara akuntansi akan menghasilkan laporan keuangan. Teknologi informasi yang dimaksud dalam penelitian ini 
adalah program aplikasi yang digunakan oleh SKPD Pemerintah Daerah Kaupaten Minahasa Selatan dalam menghasilkan informasi akuntansi. Program aplikasi Sistem Informasi Manajemen Daerah (SIMDA) telah diperkenalkan pada tanggal 09 Mei 2011 oleh Deputi Pengawasan Bidang Penyelenggaraan Keuangan Daerah bertepatan dengan pelaksanaan kegiatan Nota Kesepahaman antara Pemkab Minsel dengan Perwakilan BPKP Provinsi Sulawesi Utara dan penandatanganan action plan menuju WTP di Aula Kantor Bupati Minahasa Selatan. Program aplikasi ini dimaksudkan untuk membantu pengelolaan keuangan daerah baik di tingkat SKPKD (sebagai entitas pelaporan ) maupun di tingkat SKPD (entitas akuntansi). Tujuan pengembangan Program Aplikasi Sistem Informasi Manajemen Daerah ini adalah:

1. Menyediakan data base mengenai kondisi di daerah yang terpadu baik dari aspek keuangan, aset daerah, kepegawaian/aparatur daerah maupun pelayanan publik yang dapat digunakan untuk penilaian kinerja instansi pemerintah daerah.

2. Menghasilkan informasi yang komprehensif, tepat dan akurat kepada manajemen pemerintah daerah. Informasi ini dapat digunakan sebagai bahan untuk mengambil keputusan.

3. Mempersiapkan aparat daerah untuk mencapai tingkat penguasaan dan pendayagunaan teknologi informasi yang lebih baik.

4. Memperkuat basis pemerintah daerah dalam melaksanakan otonomi daerah.

\subsection{Keahlian Pemakai}

Menurut Laudon (2008 : 155), para pemakai (user) perlu mengetahui dan memahami teknologi informasi yang digunakan perusahaan dalam sistem informasinya. Dengan pemahaman yang baik dari pemakai, arus informasi pun akan tersampaikan dan dapat diinterpretasikan dengan baik, serta diharapkan kualitas informasi yang dihasilkan juga baik.

Keahlian pemakai menurut Bandura (2006) dalam Tata Subari (2013:76) yaitu keahlian pemakai merupakan kepercayaan seseorang yang mempunyai kemampuan untuk mengoperasikan komputer yang dipengaruhi oleh motivasi dan perilaku. Dan keahlian pemakai menurut Horrison dan Rainer dalam Anak Agung (2005:33) adalah suatu perkiraan atas suatu kemampuan sesorang untuk melaksanakan pekerjaanya dengan sukses, seseorang yang menganggap dirinya mampu untuk melaksanakan tugas dengan cenderung sukses. Sedangkan menurut Doyle (2005) dalam Tirta Sutabri (2013:76) keahlian pemakai didefinisikan sebagai penilaian individu mengenai kemampuan seseorang untuk menggunakan komputer/sistem informasi/ teknologi informasi yang depengaruhi oleh pendidikan dan pelatihan yang telah diterima.

Suatu sistem informasi dikatakan berhasil dan berkualitas ketika sistem tersebut dapat menyediakan layanan informasi serta menghasilkan informasi yang berkualitas pula. Keahlian merupakan kombinasi dari pengetahuan yang diperoleh dari pendidikan, pelatihan dan pengalaman seseorang dalam bidang tertentu yang digelutinya. Keahlian komputer dapat dikembangkan melalui pendidikan dan pelatihan. Namun kedua hal tersebut tidak maksimal jika tidak disertai dengan pengalaman. Dengan kata lain, keahlian akan lebih maksimal jika pemakai mengkombinasikan ketiganya yaitu pendidikan, pelatihan, dan pengalaman. Setelah mendapatkan pengetahuan melalui pendidikan dan pelatihan, maka pengalaman akan menjadikan pemakai lebih memahami tentang bidang yang digeluti, dalam hal ini teknologi komputer.

\subsection{Hipotesis Penelitian}

Terdapat dua hipotesis yang dikembangkan dari hipotesis-hipotesis yang di dasari dari penelitian-penelitian terdahulu yaitu :

H1: Penggunaan teknologi informasi berpengaruh positif terhadap kualitas informasi akuntansi

H2: Keahlian pemakai berpengaruh positif terhadap kualitas informasi akuntansi. 


\section{METODE PENELITIAN}

\subsection{Jenis dan Sumber Data}

Jenis data penelitian yang digunakan dalam penelitian ini adalah jenis data kuantitatif yang diukur dalam suatu skala numerik (angka) melalui kuesioner yang disebarkan oleh peneliti kepada operator SIMDA pada setiap SKPD di Kabupaten Minahasa Selatan. Sumber data di dalam penelitian ini menggunakan dua jenis data yaitu data primer dan data sekunder. Data primer diperoleh melalui penyebaran kuesioner, wawancara atau tanya jawab dari sumbernya. Data Sekunder adalah data yang diperoleh peneliti secara tidak langsung melalui media perantara yaitu melalui hasil-hasil penelitian, buku-buku, artikel, dan berbagai referensi-referensi terkait yang relevan dengan masalah yang diangkat.

\subsection{Sampel dan teknik pengambilan sampel}

Sampel adalah bagian dari jumlah karakteristik yang dimiliki oleh populasi tersebut (Sigiyono 2016:120). Kriteria responden dalam penelitian ini adalah pegawai yang bekerja dan melaksanakan tugas dan fungsi sebagai pengelola keuangan di setiap SKPD Kabupaten Minahasa Selatan. Responden dalam penelitian ini adalah seluruh operator SIMDA setiap SKPD di Kabupaten Minahasa Selatan. Teknik pengambilan sampel menggunakan non probability sampling dengan metode purposive sampling yaitu dengan kriteria operator sistem informasi manajemen daerah (SIMDA).

\subsection{Metode Analisis}

Dalam penelitian ini data yang diperoleh akan di analisis menggunakan Analisis Regresi Linear Berganda. Analisis Regresi Linear Berganda adalah analisis yang mengukur pengaruh dua atau lebih variabel independen, terhadap variabel dependen, sedangkan hubungannya tetap linear (Taniredja \& Mustafidah, 2014:92). Dimulai dengan Uji Kualitas Data yang didalamnya ada Uji Validitas dan Uji Reabilitas selanjutnya Uji Asumsi Klasik yang terdiri dari Uji Normalitas, Uji Multikolonieritas, dan Uji Heteroskedastisitas dan diakhiri dengan Analisis Regresi Linear Berganda.

\section{HASIL ANALISIS DAN PEMBAHASAN}

\subsection{Hasil Analisis}

\subsubsection{Uji Asumsi Klasik}

Uji asumsi klasik yang digunakan yaitu Uji Normalitas, Uji Multikolinearitas, Uji Hetoroskadektisitas, dan Uji Autokorelasi. Berikut hasil uji asumsi klasik dalam penelitian ini.

a. Uji Normalitas

Pengujian normalitas dalam penelitian ini dilakukan dengan menggunakan uji statistik Kolmogorov-Smirnov $(K-S)$. Dasar pengambilan keputusan nilai Sig $\geq 0,05$ maka dikatakan berdistribusi normal. Jika nilai Sig $<0,05$ maka dikatakan berdistribusi tidak normal..

Uji Normalitas

\begin{tabular}{|c|c|c|}
\hline Variabel & Asymp. Sig (2-tailed) & Keterangan \\
\hline Penggunaan Teknologi Informasi (X1) & 0,509 & $\begin{array}{c}\text { Berdistribusi } \\
\text { Normal }\end{array}$ \\
\hline Keahlian Pemakai (X2) & 0,302 & $\begin{array}{c}\text { Berdistribusi } \\
\text { Normal }\end{array}$ \\
\hline
\end{tabular}

Sumber: Data Primer diolah 2018

b. Uji Multikolinearitas

Uji Multikolinearitas bertujuan untuk mengetahui hubungan yang bermakna (korelasi) antara setiap variabel bebas dalam suatu model regresi. Multikoleniaritas dapat dilihat dari 
nilai tolerance / variance inflation factor (VIF). Jika nilai tolerance lebih besar dari 0,1 / VIF kurang dari 10, maka dapat dikatakan model telah bebas dari masalah multikolinearitas.

\section{Uji Multikolinearitas}

\begin{tabular}{|c|c|c|}
\hline Variabel & Tolerance & VIF \\
\hline $\begin{array}{c}\text { Penggunaan Teknologi Informasi } \\
(\mathrm{X} 1)\end{array}$ & 0.689 & 1.451 \\
\hline Keahlian Pemakai (X2) & 0.689 & 1.451 \\
\hline
\end{tabular}

Sumber: Data Primer diolah 2018

c. Uji Heterokedastisitas

Berdasarkan uji ini dapat diketahui bahwa tingkat signifikansi variabel bebas $\geq 0,05$ yang berarti bahwa tidak terjadi heteroskedastisitas dalam model regresi pada penelitian ini.

Uji Heterokedastisitas

\begin{tabular}{|c|c|c|}
\hline Variabel & Sig & Keterangan \\
\hline $\begin{array}{c}\text { Penggunaan Teknologi Informasi } \\
(\mathrm{X} 1)\end{array}$ & 0,366 & Bebas heteroskedastisitas \\
\hline Keahlian Pemakai (X2) & 0,05 & Bebas heteroskedastisitas \\
\hline
\end{tabular}

Sumber: Data Primer diolah 2018

Diketahui bahwa tingkat signifikansi variabel bebas $\geq 0,05$ yang berarti bahwa tidak terjadi heteroskedastisitas dalam model regresi pada penelitian ini.

\subsubsection{Uji Regresi Linear Berganda}

Pengujian hipotesis dalam penelitian ini menggunakan analisis regresi linear berganda dengan bantuan program SPSS 21 . Hasil dari regresi linear berganda dalam penelitian ini dapat dilihat pada tabel berikut

Hasil Analisis Regresi

\begin{tabular}{|c|c|c|c|c|c|}
\hline \multirow[t]{2}{*}{ Model } & \multicolumn{2}{|c|}{ Unstandardized Coefficients } & Standardized & \multirow[t]{2}{*}{$\mathrm{T}$} & \multirow[t]{2}{*}{ Sig. } \\
\hline & B & Std. Error & Beta & & \\
\hline (Constant) & -.654 & .599 & & -1.092 & 279 \\
\hline $\begin{array}{l}\text { Teknologi } \\
\text { Informasi }\end{array}$ & 642 & .073 & .810 & 8.776 & .000 \\
\hline $\begin{array}{l}\text { Keahlian } \\
\text { Pemakai }\end{array}$ & .503 & .080 & .577 & 6.250 & 000 \\
\hline $\mathrm{R}^{2}$ & Adj & & $\mathrm{F}$ & & Sig. \\
\hline .580 & & & 42.0 & & .000 \\
\hline
\end{tabular}

Sumber: Data Primer diolah 2018

1. Uji F

Uji ini menunjukkan apakah semua variabel independen yang dimasukkan dalam model mempunyai pengaruh secara simultan terhadap variabel dependen. Apabila nilai signifikansi lebih besar dari 0,05 berarti bahwa variabel independen secara bersamaan memiliki pengaruh terhadap variabel dependen. Berdasarkan tabel tersebut dapat dilihat bahwa dalam penelitian ini variabel independen tidak mempunyai pengaruh secara bersamasama terhadap variabel independen dengan nilai signifikansi 0,000 .

\section{Adjusted $\mathbf{R}^{2}$}

Nilai adjusted $\mathrm{R}^{2}$ menunjukkan seberapa besar variabel dependen dapat dijelaskan oleh variabel independen. Nilai adjusted $\mathrm{R}^{2}$ dapat dilihat pada tebel 4.11 yaitu sebesar 0,566 . 
Hal ini menunjukkan bahwa dalam penelitian ini variabel dependen yang dapat dijelaskan oleh variabel independen sebesar 56,6 \%, sedangkan sisanya yaitu sebesar 53,4\% dijelaskan oleh variabel lain yang tidak termasuk dalam penelitian ini.

\section{Uji t}

Uji $\mathrm{t}$ digunakan untuk mengetahui pengaruh masing-masing variabel independen terhadap variabel dependen. Hipotesis diterima jika nilai signifikansinya lebih kecil dari 0,05 dan hipotesis ditolak jika nilai signifikansinya lebih besar dari 0,05 .

\subsection{Pembahasan}

a. Pengujian Hipotesis Pengaruh Penggunaa Teknologi Informasi terhadap Kualitas Informasi Akuntansi

Berdasarkan hasil Analisis Regresi Linear Berganda dapat dilihat bahwa nilai signifikansi variabel penggunaan teknologi informasi sebesar 0,000 . Hal menunjukkan bahwa nilai signifikansi variabel pengguna teknologi informasi lebih kecil dari 0,05. Seperti yang telah dijelaskan sebelumnya, hipotesis akan diterima jika nilai signifikansi kurang dari 0,05. Maka dapat disimpulkan bahwa hipotesis 1 diterima yang berarti penggunaan teknologi informasi berpengaruh terhadap kualitas informasi akuntansi.

Teknologi informasi merupakan gabungan antara teknologi komputer dan teknologi komunikasi. Komponen utama teknologi informasi adalah hardware, software, dan brainware.

Penggunaan teknologi informasi ternyata berdampak baik terhadap kualitas informasi akuntansi. Hal ini terbukti dengan penelitian yang di lakukan pada SKPD yang ada di Kabupaten Minahasa Selatan. Dimana penggunaan teknologi informasi sudah mempengaruhi kualitas informasi akuntansi dalam hal ini laporan keuangan dengan menggunakan Sistem Informasi Manajemen Daerah (SIMDA). Hasil penelitian ini tidak sejalan dengan penelitian sebelumnya yaitu Riska Fitriyani (2014) yang menyatakan bahwa penggunaan teknologi informasi tidak berpengaruh positif signifikan terhadap kualitas informasi akuntansi di Provinsi Bengkulu karena saat penelitian ini dilakukan aplikasi SIMDA baru digunakan di Provinsi Bengkulu. Namun penelitian lainnya mendukung penelitian ini, M.Turnip (2015) menyatakan bahwa penggunaan teknologi informasi akuntansi berpengaruh positif signifikan terhadap kualitas informasi akuntansi di kantor pusat PT Pos Indonesia Bandung dan Nova Evania (2016) yang menyatakan bahwa dengan adanya penggunaan teknologi informasi, maka akan memberikan dampak positif terhadap instansi dan memberikan keuntungan ekonomi karena penggunaan teknologi informasi tersebut akan membantu dalam memperbaiki kualitas informasi

b. Pengujian Hipotesis Pengaruh Keahlian Pemakai Terhadap Kualitas Informasi Akuntansi

Hasil Analisis Regresi Linear Berganda menunjukkan nilai signifikansi variabel penggunaan teknologi informasi sebesar 0,000 . Hal ini berarti bahwa nilai signifikansi variabel keahlian pemakai lebih besar dari 0,05. Maka dapat disimpulkan bahwa hipotesis 2 diterima yang berarti keahlian pemakai berpengaruh signifikan terhadap kualitas informasi akuntansi.

Pemakai yang memiliki keahlian dan pemahaman terhadap sistem yang digunakan pemakai akan merasa lebih memiliki sistem yang digunakan itu, sehingga mereka dapat menggunakan sistem dengan baik. Dengan pemahaman yang baik dari pemakai, arus informasi pun akan tersampaikan dan dapat diinterpretasikan dengan baik, serta diharapkan kualitas informasi yang dihasilkan juga baik.

Berdasarkan penelitian ini keahlian pemakai berpengaruh terhadap kualitas informasi akuntansi dalam hal ini laporan keuangan dengan menggunakan Sistem Informasi 
Manajemen Daerah (SIMDA). Hasil penelitian ini sejalan dengan penelitian Mardia Rahmi (2013) yang menyatakan bahwa semakin tinggi keahlian pemakai sistem informasi akuntansi maka kualitas informasi akuntansi akan semakin baik

\section{KESIMPULAN DAN SARAN}

\subsection{Kesimpulan}

Dari hasil analisa dan pembahasan mengenai pengaruh penggunaan teknologi informasi dan keahlian pemakai terhadap kualitas informasi akuntansi pada SKPD di Kabupaten Minahsa Selatan dapat disimpulkan sebagai berikut :

1. Penggunaan teknologi informasi terhadap kualitas informasi akuntansi berpengaruh signifikan terhadap kualitas informasi akuntansi dengan nilai signifikan 0,000>0,05 dari hasil regresi linear berganda dalam uji t pada SKPD di Kabupaten Minahasa Selatan

2. Keahlian pemakai terhadap kualitas informasi akuntansi berpengaruh signifikan terhadap kualitas informasi akuntansi dengan nilai signifikan 0,000 $>0,05$ dari hasil regresi linear berganda dalam uji t pada SKPD di Kabupaten Minahasa Selatan

\subsection{Saran}

Berdasarkan hasil penelitian maka dapat diberikan beberapa saran berikut :

1. Penelitian selanjutnya lebih baik menggunakan sampel yang lebih banyak lagi, dibandingkan penelitian ini, agar hasil yang didapatkan bisa lebih akurat.

2. Penelitian selanjutnya dapat menggunakan variabel bebas lainnya sehingga untuk selanjutnya dapat ditemukan variabel baru yang akan mempengaruhi kualitas laporan keuangan pemerintah daerah.

3. Penelitian selanjutnya diharapkan menambahkan variabel independen lain yang dapat menjelaskan variabel dependen, sehingga nilai adjusted $\mathrm{R}^{2}$ menjadi lebih besar.

\section{DAFTAR PUSTAKA}

Anak Agung dan I Nyoman Putra, (2005), Pemanfaatan TI dan Pengaruhnya pada Kinerja Individual Bank Perkreditan Rakyat di Kabupaten Tabanan, Jurnal Akuntansi, vol 5 no 1.

Azhari, S., Diah, R., \& Cahyono, Y. T. (2016). Pengaruh Kapasitas Sumber Daya Manusia, Pemanfaatan Teknologi Informasi, dan Pengendalian Intern Akuntansi terhadap Nilai Informasi Pelaporan Keuangan Pemerintah Daerah (Studi Kasus pada Dinas Kabupaten Wonogiri) (Doctoral dissertation, Universitas Muhammadiyah Surakarta)..

Evania, N., Taufik, T., \& Hasan, M. A. (2016). Pengaruh Penggunaan Teknologi Informasi, Keahlian Pemakai, Dan Intensitas Pemakaian Terhadap Kualitas Informasi Akuntansi (Studi Pada Satuan Kerja Perangkat Daerah Kabupaten Indragiri Hulu). Jurnal Online Mahasiswa (JOM) Bidang Ilmu Ekonomi, 3(1), 635-649.

Fitriyani, R., \& Lismawati, L. (2014). Pengaruh Penggunaan Teknologi Informasi, Keahlian Pemakai dan Intensitas Pemakaian terhadap Kualitas Informasi Akuntansi.(Doctoral dissertation, Universitas Bengkulu)..

Indonesia, R. (2006). Peraturan Pemerintah Nomor 8 Tahun 2006 tentang Pelaporan Keuangan dan Kinerja Instansi Pemerintah. Jakarta, Fokusmedia.

Loudon, Kenneth C. \& Jane P. Laudon. 2012. Management Information Systems: Managing the Digital Firm. 12th Edition. NJ: Prentice-Hall.

Negash, S., Ryan, T., and Igbaria, M. 2003. Quality and Effectiveness in Web Based Customer Support Systems. Information \& Mangement, 40(8): 757-768.

No, P. P. (71). Tahun 2010 tentang. Standar Akuntansi Pemerintah 
Ong, C.S., Day, M.Y., and Hsu, W.L. 2009. A Measurement of User Satisfaction with Question Answering Systems. Journal of Information and Management. 46(7), $h$ : 397403

Rahmi, M. (2013). Pengaruh Penggunaan Teknologi Informasi Dan Keahlian Pemakai Terhadap Kualitas Informasi Akuntansi (Studi Empiris Pada Perusahaan BUMN di Kota Padang). Jurnal Akuntansi, 1(2).

Simkin, M. G., Norman, C. S., \& Rose, J. (2013). Accounting information systems. John Wiley \& Sons.

Sugiyono. 2016. Metode Penelitian Kombinasi. Bandung, Alfabeta.

Susanto, A. (2013). Accounting information systems: Development of risk control structure. Prime Edition. First mold. Bandung: Lingga Jaya

Sutabri, Tata. 2013. Komputer dan Masyarakat. Yogyakarta: CV. Andi.

Turnip, M.(2015) Pengaruh Teknologi Informasi dan Kemampuan Pengguna Terhadap Kualitas Sistem Informasi Akuntansi (Studi Kasus Pada Kantor Pusat PT. Pos Indonesia Kota Bandung). 